\title{
Cooperation between non-governmental organizations and the State in the matter of flood risk management in the Czech Republic
}

\author{
J. Dostál \\ Department of Public Economics, Faculty of Economics and \\ Administration, Masaryk University, Czech Republic
}

\begin{abstract}
The purpose of this paper is to identify the current form of cooperation between non-governmental organizations (NGOs) and the State in flood risk management in the Czech Republic. The institutional framework developed for the broad cooperation between the State and the nonprofit sector was applied to flood risk management as a means of examining this area. The institutional framework for NGOs-State cooperation in the case of Czech flood risk government has the following elements: the European Union, Central Government, Ministries, Regional Authorities, Municipal Authorities, Emergency Services of Integrated Rescue System, Qua-volunteers, Employment Agencies, and State Companies. The methodology was qualitative and revolved around a literature review and managed interviews with six prominent NGOs participating in Czech flood risk management. Further data was collected from Czech professionals' conferences and during the author's membership in the working group of the Ministry of Interior of the Czech Republic. The conclusion of the paper is as follows: The overview of the cooperation could be helpful for other post-socialistic countries which face a similar situation as did the Czech Republic Moreover, an overview of all forms of NGOs-State cooperation in the case of Czech flood risk management could be helpful for Czech NGOs and the Czech State where cooperation is variable at all levels of governance across the country.

Keywords: flood, Czech Republic, flood risk management, non-governmental organizations, state, cooperation, institutional framework.
\end{abstract}




\section{Introduction}

Palubinskas [1] notes that the implementation of communism in Central and Eastern Europe resulted in the virtual elimination of NGOs. After the establishment of democracy, Czechoslovakia (and later the Czech Republic) faced the challenge of how to involve NGOs in flood risk management. This became a particular focus in 1997 after the first big flood event in the Czech Republic following the demise of communist rule.

Czechoslovakia was not an exception. Many Eastern Bloc countries also faced a virtually eliminated NGO sector, a situation that could be considered point zero of NGOs' participation in flood risk management. The Czech Republic faced two challenges: first to establish civil society and secondly to manage a new type of flood, which affected the country. These two challenges merge into one in the case of participation of NGOs into Czech flood risk management.

An examination of the academic literature reveals a distinct gap on this topic. Studies by Frič et al. [2], Brhlíková [3], Hyánek and Pospíšil [4] and the others focus on non-profit sector in the Czech Republic in general, while Rektořík [5], Antušák and Kopecký [6] focus on emergency management in the Czech Republic in general. Kavan [7] writes about civil protection in the Czech Republic and also partly about cooperation between NGOs and Czech state in case of emergency management especially about the cooperation between NGOs and Fire Rescue Service of the Czech Republic. But he highlights one significant fact; both NGOs and Czech state need each other and are dependent on each other today.

In case of Czech flood risk management, studies focusing on NGOs were almost nonexistent. One exception is Kumar [8], who wrote about the flood in 2002 and focused particularly on coordination of humanitarian help of NGOs in the case of flood. But that is only a small piece of NGO-state cooperation in flood risk management. Moreover situation in Czech flood risk management and NGOs participation and cooperation with state in year 2011 or 2012 appears to be very different than in 2002 .

During the review of the literature, literature presenting complex reviews of cooperation between NGOs and regional and municipal governments in case of flood risk management was not found. The most valuable literary source was the research report from Rektořik et al. [9], written by a collective of scholars including the author. This report has several parts; one of them was regarding NGOs and their cooperation with local authorities.

This paper's purpose is to identify a current form of NGOs-State cooperation in terms of Czech flood risk management. This was achieved through application of the theoretical approach with a general institutional framework to the current situation of Czech flood risk management. 


\section{Material and methods}

Methodology was qualitative and revolved around a literature review, managed interviews and information gathered during sessions of relevant working group of Ministry of Interior of the Czech Republic.

Primary data was collected through managed interviews with six prominent NGOs participating in Czech flood risk management. The interviews took place during the first half of year 2011. The Snowball method was used for choosing the NGOs, starting with the most respected ones, and then moving on to others along the chain. The circle was closed at $n=6$. The list of the chosen NGOs can be found in table 1. Although there are many other NGOs participating in the Czech flood risk management process, the NGOs selected appear to be the most prominent participants.

Table 1: NGOs which take part in the research.

\begin{tabular}{|c|c|}
\hline NGO & Position of the NGO representatives \\
\hline ADRA & $\begin{array}{c}\text { Coordinator of the humanitarian help in the Czech } \\
\text { Republic; Economic director }\end{array}$ \\
\hline Czech Red Cross & President \\
\hline People in Need & Coordinator and head of flood programs. \\
\hline Diaconia & Person, responsible for humanitarian aid. \\
\hline Hand for Help & Managing director \\
\hline $\begin{array}{c}\text { Caritas Czech } \\
\text { Republic }\end{array}$ & $\begin{array}{c}\text { Head of humanitarian department - Archdiocesan Caritas } \\
\text { Olomouc }\end{array}$ \\
\hline
\end{tabular}

After choosing the NGOs for managed interviews, it was necessary to identify relevant positions and the persons who occupy them to be interviewed. Because of need to make the findings relevant, of the findings, simple logic was used: as high relevant position as possible. The result of these efforts was that managed interviews were achieved with two heads of NGOs, one economic director and in four cases, with persons responsible for humanitarian aid in the Czech Republic. Positions of the NGOs representatives, which were asked during the managed interviews, are available in the following table.

All the NGOs were extremely willing to cooperate to participate in this research, including the CEOs. These interviews with NGOs were a central part of the research because they represent the main players in this field.

After the first part of research in June 2011, the author was invited to be a member of a working group of Ministry of Interior of the Czech Republic called Volunteering and Emergency and Crisis situation. During the participation and membership of the working party additional information was able to be gathered.

\section{Results}

Bullain and Toftisova's [10] institutional framework, in its original general terms was used. Their framework has eight levels of NGO cooperation with 
government: Parliament, Central Government, Ministries, Agencies and authorities, Councils or joint committees, Quangos, Specific Bodies and Local form of cooperation. In this paper you can see the application of this framework on current situation in Czech flood risk management. Because of the quite specific character of this part of non-profit sector, the general framework was modified.

The new institutional framework for NGOs-state cooperation in the case of Czech flood risk management has the following elements: European Union, Central Government, Ministries, Regional Authorities, Municipal Authorities, Emergency Services of Integrated Rescue System, Qua-volunteers, Employment Agencies and State or Half-state Companies.

\subsection{European Union}

A special case of cooperation of Czech NGOs with a central form of government is the cooperation with the European Union. NGOs could use cooperation with the European Union as a strategy for gaining financial recourses for Czech flood risk management work.

The truth is that the NGOs involved in Czech flood risk management have had some experiences with projects supported by Structural Funds, but in most cases these projects are from areas not related to flood risk management activities. For example, ADRA has a project for assisting the victims of domestic violence and working with children with behavioral problems. The only project supported by Structural Funds related to flood risk management, are projects of Czech Red Cross for disaster preparedness.

\subsection{Central government}

The central government in this context means the central government of the Czech Republic and its councils.

\subsubsection{Central taskforce}

The more important council of the central government is the National Security Council. The working body of the National Security Council which is important for cooperating with NGOs in case of Czech flood risk management is called Central Taskforce. It was found out that Czech Red Cross had already taken part in this session. This is an example of another form of cooperation between NGOs and the Central Government which impacts on Czech flood risk management.

\subsubsection{Government council for non-governmental non-profit organisations}

The second relevant Government Council is the Council for Non-Governmental /Non-Profit Organisations. The council has several committees that include the Committee for Regions whose role it is to encourage the NGOs-Regional government's relations and The Committee for Legislation and Finance whose role it is to regulation of the non-profit sector [11]. Previously three laws were prominent in relation to NGO participation in flood risk management: the law on 
public benefit, law on financial collection and civil code. One of the present members of this Council is the director of Caritas Czech Republic which is one of the primary NGOs participating in Czech flood risk management [12].

\subsection{Ministries}

The cooperation between NGOs and ministries has several forms. In general, they include the accreditation service and provide grants and organize the working groups of the Ministry.

\subsubsection{Accreditation service and providing grants}

The Ministry of the Interior operates an accreditation service for NGOs providing voluntary assistance. The accreditation system is closely connected to the provision of grants to NGOs. The accreditation and grant system is used by various kinds of services, not only for volunteerism as a part of flood risk management. There are two commissions for that purpose: Accreditation Commission and the Grant Commission.

Both of them have 9 members and some of the members are the same. The members of the commission are also representatives of other ministries (Foreign Affairs; Labour and Social Affairs; Finance; Culture; Education, Youth and Sport; Environment) [13]. Therefore it can be said that by meeting the rules of these commissions and communication with them, NGOs participating in Czech flood risk management are also cooperating with these other ministries, through its representatives.

In 2011 it was found that several grants from Czech ministries relating to Czech flood risk management to NGOs came from sources of ministries. The Ministry of the Interior, for example, provided a financial contribution to ADRA for crisis and emergency plans. The Ministry of Education, Youth and Sport also gave financial assistance to ADRA for activities related to the organization of European Year of Volunteering in the Czech Republic - 50000 CZK). Some NGOs receive grants from the General Directorate of the Fire Rescue Service of the Czech Republic which is the part of the Ministry of Interior. (e.g. the Czech Red Cross receive 30000 CZK, while Diaconia receive between 40000 to 60000 CZK per year).

\subsubsection{Working group of ministry}

Another form of cooperation between NGOs and Government Agencies in relation to Czech flood risk management is the Ministry of Interior working group for Volunteering and Emergency and Crisis situations. This group was established during the European Year of Volunteering. Attached to this working group are representatives from the Ministry of Interior, ADRA, the Czech Red Cross, Diaconia, Caritas and also from South Bohemian regional authority, ČEZ group, the General Directorate of Fire Rescue Service, Voluntary fire service and Masaryk University. One of the main goals of the group is encouraging mutual cooperation among NGOs, public administration and corporate volunteering. 


\subsubsection{Regional authorities}

On a regional level, there are several form of cooperation with NGOs: Integration into the regional crisis plans, regional taskforce session, certification of public collections, regional PANEL and professionals' conferences

\subsubsection{Integration into the regional crisis plans}

NGOs are integrated into regional crisis plans in two ways: direct and indirect. Direct integration refers to an NGO role and participation in the regional crisis plan, while indirect integration occurs when an NGO are integrated through the Fire Rescue Service and the Fire Rescue Service is directly integrated into the regional crisis plan (see parts 'Emergency services of Integrated Rescue System')

An example of a direct integration is Diaconia. It is integrated into the crisis plan of Zlín Region. Examples of indirect integration are Caritas and ADRA, which are integrated into the crisis plans through Fire Rescue Service as an emergency service of Integrated Rescue System. NGOs also have opportunity to comment regional crisis plans (e.g. ADRA in South Moravia Region, Karlovy in the Vary Region, Liberec Region, and South Bohemia Region).

\subsubsection{Regional taskforce session}

Each region has its own task force for managing the crisis situations and in these task forces, NGOs representatives occasionally participate. We already have in the Czech Republic several examples of this type of participation, e.g. the Czech Red Cross, which takes part in task force sessions in many of regions and People in Need take part in Liberec Region task force.

Regardless, all NGOs have declared their willingness to take part in these sessions and all of them are convinced that they have something to offer. According to the NGO's, the sharing of information is a significant benefit of cooperation. Sharing information with NGO's could also be considered the biggest benefit on the municipal level (see part 'Municipal Authorities')

\subsubsection{Certification of public collections}

According to law on public collections [14], the Regional Governments of the Czech Republic or the Municipal Office of Prague give approval (certification) for the collection of money in the form of donations from the public. Money from public collections is an important part of financing participation of NGOs in Czech flood risk management.

\subsubsection{Regional PANEL}

On a regional level, is PANEL is another possible form of cooperation for NGOs, Unfortunately, PANELs are currently operating in only 3 regions from 14 (including Prague). Moreover even among these three regions there are significant differences. The South Moravia PANEL has signed contracts but there are doubts about practicality of the contracts working. In Ústí nad Labem region, PANEL is working but without the financial support of the regional government and in South Bohemia Region, PANEL enjoys significant financial support from regional government. 
Each PANEL has its own unique structure. Among professionals from Czech emergency management there is relative consensus that the South Bohemia PANEL is currently the best available variant. In general one could say that PANEL is the working group for cooperation between NGOs and regional governments and for coordination of NGOs.

The South Bohemian Regional government has contracts with members of PANE. In 2011these included contracts with the Association of Firefighters of Bohemia, Moravia and Silesia, ADRA, Caritas and the Czech Red Cross) The regional government is providing financial assistance to these NGOs (470 $000 \mathrm{CZK}$ to Association of Firefighters of Bohemia, Moravia and Silesia, $720000 \mathrm{CZK}$ to Czech Red Cross, $80000 \mathrm{CZK}$ to ADRA and $80000 \mathrm{CZK}$ to Caritas, per annum in all cases.). If there is no emergency during the year, the NGOs use this money to finance their usual activities. NGOs also have the opportunity to request an increased financial assistance from the regional government if necessary. In the event of an emergency, an evaluation report is produced at the conclusion of the agency's emergency participation.

Through PANEL the NGOs have assigned roles to cope with the emergency. Czech Red Cross, for example, assumes the role of emergency coordinator; ADRA is providing seminars for volunteers, while the Association of Firefighters of Bohemia is cooperating with task force etc.

The South Bohemian PANEL is considered the best variant at present. Therefore the Czech Republic Ministry of the Interior are currently creating a model based on the South Bohemian PANEL structure for use as a standard in setting up other PANEL working group across other regions. That is not to say the model cannot be adapted to better suit local conditions but at present it is the optimal model. At present, it is expected that the Ministry of Interior Volunteering and Emergency and Crisis situations working group will coordinate these activities. One interesting opinion suggests that PANEL is the nonprofit sector's version of Integrated Rescue System.

\subsubsection{Professionals' conferences}

On the regional level, the conference platform is used as a means of introducing the problems, capabilities and needs of NGOs, local governments, Fire Rescue Service, volunteer firefighters etc. to each other. Some of these conferences in several regions are called 'Do we know about each other?' are initiated and supported by regional governments. South Bohemia region is an example of this.

\subsection{Municipal authorities}

Also on a municipal level, are several forms where cooperation with NGOs and their contribution were recognized - Integration into the municipal crisis plans, municipal taskforce session, municipal PANEL and helping the municipality to provide social service.

\subsubsection{Integration into municipal crisis plans}

As in case of regional governments, municipalities are cooperating with NGOs to develop or improve local crisis plans. An example of this direct form of 
integration is Hand for Help who have representation and a specified role in the crisis plan of municipality of Hrádek nad Nisou.

\subsubsection{Municipal taskforce sessions}

Several examples of participation by NGOs in Municipal task force sessions can be found. Czech Red Cross is taking part in task force sessions in many municipalities. People in Need participate in the municipalities of Nový Jíćín and Frýdlant. NGOs cooperate by sharing information with municipality governments and representation at the municipality government level - mayor, crisis managers etc.

This cooperation is quite important in the event that a flood occurs. Similar to the regional level, the participation of NGO's in flood task force session is having a positive effect and is to be recommended. For the same reason, it seems to be also more convenient for NGOs to delegate one representative to take part in task force session.

\subsubsection{Municipal PANEL}

Also at municipality level the PANEL cooperation is occurring (f. e. Děčín in Ústí nad Labem Region and Česká Lípa in Liberec Region), even this platform is still not common on the municipal level.

\subsubsection{Helping the municipality with providing social services}

An interesting example of NGOs - municipal government cooperation came as a result of the big flood in 1997. At that time, Czech Red Cross was building retirement houses in areas affected by flood. Subsequently most of them were given to municipal authorities.

\subsection{Emergency service of integrated rescue system}

This type of cooperation has several forms: cooperation at the moment of the emergency, contracts between the Fire Rescue Service and NGOs, cooperation at taskforce session, professionals' conferences and working group of ministry

\subsubsection{Cooperation at the moment of emergency}

Integrated Rescue System is based on emergency services of the Integrated Rescue System (Fire Rescue Service of the Czech Republic and Fire Units, Police of the Czech Republic and Medical Rescue Service). But according to law on the Integrated Rescue System [15], there are also other emergency services of the System and one of them are NGOs. All are considered elements of the system and all elements are expected to cooperate when dealing with an emergency.

It is obvious that in case of emergency the NGOs will have to cooperate with emergency services of Integrated Rescue System such as Fire Service and Fire Units, Police and Medical Rescue Service. In the event of a flood NGOs, particularly volunteers, must be able to communicate with the commander of Integrated Rescue System during the intervention. 


\subsubsection{Contracts between the fire rescue service and NGOs}

The most important aspect of NGOs cooperation with emergency service of Integrated Rescue System in Czech flood risk management is contact with the Fire Rescue Services. Some NGOs (ADRA, Caritas) direct communication with the Fire Rescue Services and through them the NGOs are integrated into regional crisis plans.

Kavan [7] mentions three possible types of contracts between NGOs and the Fire Rescue Service in Integrated Rescue System of the Czech Republic: contract about the planned help on request; contract about the provision of personal or material assistance and contract about the cooperation.

\subsubsection{Cooperation at taskforce session}

Representatives from sectors of the Integrated Rescue System take part in Task Force meetings along with NGOs representatives where information sharing can occur.

\subsubsection{Professionals' conferences and working group of ministry}

Many representatives of Fire Rescue Services regularly take part in professional conferences about volunteering in emergency management both at the central level (provided by Ministry of the Interior) and the local level (provided by regional governments.) These conferences are by other levels of Government and relevant NGO representatives.

The Fire Rescue Service is represented in Working group of Ministry of Interior Volunteering and Emergency and Crisis situation.

\subsection{Qua-volunteers}

This category is a modification of Bullain and Toftisova's [10] category called Quango. According them, Quangos straddle the line between the state and organized civil society. In this newly established category the situation is a little different. In this case, qua-volunteers are voluntary firemen. They are usually members of volunteer firefighters NGOs, but at the same time they are also members of voluntary fire service.

They work on voluntary basis but as soon they decide to be a member of voluntary fire service units of the municipality, they have to obey orders. According to Czech legislature, a voluntary fire service unit is an organizational unit of the municipality and it is founded and financed by municipality. Their members also have some obligation toward municipality.

Voluntary fire service units are emergency service of the Integrated Rescue System. The voluntary firemen were placed in this category because of their specific characteristics. Apart from cooperation during a flood event while in their role as part of an Integrated Rescue System, the voluntary firemen are also share information with other NGO's during the professional conferences and participation in working groups such as Volunteering and Emergency and Crisis situation of Ministry of Interior. 


\subsection{Employment agency}

In case of Czech flood risk management has appeared in the past one interesting example of this cooperation. Current Czech legislature requires that people registered at an Employment agency must fulfill certain terms and conditions. Without fulfilling the terms after some time, they are not receiving the unemployment support anymore. One of these terms and conditions is public service, which can be done also in some NGO. There is a one new thing according the law is now not possible to do this public service by volunteering according the law on volunteering. [16].

According the past legislative (before 2012) the situation was a little bit different. Public service was not obligatory for receiving social benefits, but it was an option for receiving extra money from the state. Also it was possible to do it by volunteering according the law on volunteering [16]. These people already took part in case of Caritas Czech Republic's participation in Czech flood risk management in 2010.

\subsection{State or half-state companies}

This category is not commonly considering when examining cooperation between NGOs with state. But some companies where the state holds a majority shareholding in the company of are contributing in this area. One such company is the energy conglomerate ČEZ. The state holds approximately $70 \%$ [17] of the shares in this company. ČEZ, not only donates for purposes of flood risk management, but is also supportive in other ways. For example, ČEZ has a quite sophisticated system of releasing employees for volunteering, including volunteering in flood risk management. It is also providing the graphics for promotional material on volunteering in the event of an emergency. A ČEZ representative is a member of working group of Ministry of Interior Volunteering and Emergency and Crisis situation therefore should be considered alongside NGOs in flood risk management.

Another example is Česká televize (ČT), a public television broadcaster in the Czech Republic. In February 2012, ČT introduced a project called crisis map of Czech. The project was launched in cooperation with the world volunteer network, The Standby Task Force. Prior to the launch of the project, discussions were held with NGOs specializing in humanitarian services for relevant data on which to base the project [18].

\section{Conclusion}

The study provides a unique point of view on the type of cooperation, in its various forms, between NGOs and Czech state. An overview of this type of cooperation could be helpful for other post-socialistic countries, faced with similar circumstances as the Czech Republic. That is trying to build civil society and infrastructure from the void left by the communist regime and the growing problem of floods. 
It could provide another point of view for consideration by foreign NGOs and their states on how the system works in this area in the Czech Republic for countries with similar pasts. Further research could investigate what factors influence success or otherwise of the cooperative process between NGO's and Czech Government Agencies as well as identify what successful cooperation means. Why this is important is obvious.

If other post-socialistic countries want to gain understanding of the Czech experience in this area for application in their own country, it is not enough just to say that we moved from point A to point B but also how. It is not easy to answer the question of how but it should be possible to identify factors of successful cooperation, or factors which impede cooperation. These factors should be analyzed and compared and universal truths draw out if they are there.

Moreover, this overview of all forms of NGOs - State cooperation related to Czech flood risk management could be helpful for Czech state and NGOs because cooperation is so variable at all levels across the country. From past Czech experiences one can assume that floods will occur whether or not the region affected has a well-developed system or not.

The study also suggests areas that require further research particularly the economic justification of financial support of the PANEL platform, projects from European funds as additional financial sources, status of voluntary firemen in the Czech Republic, well as the need for deeper research into the participation of state companies in some kind of emergency management.

\section{References}

[1] Palubinskas, G. T. (2003) 'Democratization: The Development of Nongovernmental Organizations (NGOs) in Central and Eastern Europe', Public Administration and Management, vol. 8 No. 3.

[2] Frič, P., Deverová, L., Pajac, P., Šilhánová, H. (1998) 'Defining the Nonprofit Sector: The Czech Republic.' Working Papers of the Johns Hopkins Comparative Nonprofit Sector Project, No. 27, Baltimore: The Johns Hopkins Institute for Policy Studies.

[3] Brhlíková, P (2004) 'The Nonprofit Sector in the Czech Republic.', Discussion Paper No. 2004-128, Praha: CERGE-EI, Charles University.

[4] Hyanek, V., Pospišil, M. (2007) Country-Specific Situation of the Nonprofit Sector in the Czech Republic, Brno.

[5] Rektořík, J. a kol. (2004) Krizový management ve veřejné správě. Praha: Ekopress. s. 250. ISBN 80-86119-83-1

[6] Antušák, E., Kopecký, A. (2005) Krizový management. Úvod do teorie.

[7] Kavan Štěpán. Ochrana obyvatelstva I. Vysoká škola evropských a regionálních studií, České Budějovice, 2011, 109 p.

[8] Kumar, P. (2005) NGO Coordination in Humanitarian Action: The Case of the Czech Floods of August 2002, Massachusetts Institute of Technology.

[9] Rektořík, J., Šelešovský J., Bakoš, E., Dostál. J., Furová, L., Šrámková, T., Smutný, M. (2011) 'Zpráva z výzkumného projektu "Ekonomické a finanční dopady živelních pohrom”", Brno. 
[10] Bullain, N., Toftisova R. (2005) 'A Comparative Analysis of European Policies and Practices of NGO-Government Cooperation', The International Journal of Not-for-Profit Law, vol 7, No. 4.

[11] Government Council is the Council for Non-Governmental /Non-Profit Organisations. Basic information. http://www.vlada.cz/cz/ppov/rnno/ zakladni-informace-767/

[12] Government Council is the Council for Non-Governmental /Non-Profit Organisations. Members of the council http://www.vlada.cz/cz/ppov/rnno/ clenove/default.htm

[13] Ministry of the Interior of the Czech Republic. Voluntary service. http://www.mvcr.cz/clanek/dobrovolnicka-sluzba-500539.aspx?q=Y2hud $\mathrm{W} 09 \mathrm{Mw} \% 3 \mathrm{D} \% 3 \mathrm{D}$

[14] Law no. 117/2001 on public collections

[15] Law No. 239/2000 on the Integrated Rescue System § 4 (2)

[16] Ministry of the Interior of the Czech Republic. Vyjádření ke změnám v souvislosti se Sociální reformou I. http://www.mvcr.cz/soubor/ dobrovolnicka-sluzba-x-verejna-sluzba-2012-doc.aspx

[17] ČEZ annual report (2012).

[18] Crisis map of Czech http://www.ceskatelevize.cz/ct24/media-atechnologie/164631-krizova-mapa-ceska-divaci-v-roli-novinaru-prikrizovych-situacich/ 